\title{
The Effect of Reading Interest and Achievement Motivation on Students' Discourse Analysis Competence
}

\section{Fitria Aprilia \\ Ninuk Lustyantie ${ }^{2 \rtimes(D)}$ \\ Zainal Rafli ${ }^{3}$}

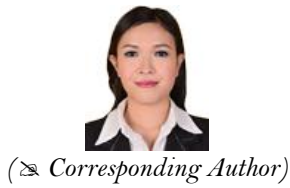

( Corresponding Author)

${ }^{1,2, s}$ Language Education Postgraduate Program, Universitas Negeri Jakarta, Indonesia.

Email:_ustyantienuk@gmail.com

\section{Abstract}

Discourse analysis involves analyzing the language being used. This research investigates the effect of reading interest and achievement motivation on students' discourse analysis competence. To obtain the required data, questionnaires on reading interest and achievement motivation, and discourse analysis were used to test the aspects of cohesion and coherence and were administered to a group of 60 students of the English language study program at Bina Darma University in Palembang. Students' reading interest and achievement motivation are some of the most crucial issues in the field of education. To analyze the data, path analysis was used and the results showed a positive direct effect on (1) reading interest of students' discourse analysis competence with a coefficient value 0.253 , and (2) achievement motivation on students' discourse analysis competence with a coefficient value 0.284 . The magnitude of the direct effects of reading interest and achievement motivation on students' discourse analysis was $44.6 \%$.

Keywords: Reading interest, Achievement motivation, Discourse analysis competence, Language, Learning undergraduate students.

Citation | Fitria Aprilia; Ninuk Lustyantie; Zainal Rafli (2020). The Effect of Reading Interest and Achievement Motivation on Students' Discourse Analysis Competence. Journal of Education and eLearning Research, 7(4): 368-372.

History:

Received: 27 July 2020

Revised: 20 August 2020

Accepted: 25 September 2020

Published: 2 November 2020

Licensed: This work is licensed under a Creative Commons

Attribution 3.0 License (cc))

Publisher: Asian Online Journal Publishing Group
Acknowledgement: All authors contributed to the conception and design of the study.

Funding: This study received no specific financial support. Competing Interests: The authors declare that they have no conflict of interests.

Transparency: The authors confirm that the manuscript is an honest, accurate, and transparent account of the study was reported; that no vital features of the study have been omitted; and that any discrepancies from the study as planned have been explained.

Ethical: This study follows all ethical practices during writing.

\section{Contents}

1. Introduction

2. Method of the Research 


\section{Contribution of this paper to the literature}

This study contributes to the existing literature by putting forth empirical proof that discourse analysis competence is influenced by reading interest.

\section{Introduction}

Discourse analysis involves analyzing the language being used. Therefore, it is not only limited to a single/independent description of the form or function of a language that is designed to facilitate all human affairs. In line with the view that language consists of forms and meanings, the relationships in a discourse can be divided into two relationship forms, one being cohesion and the other, semantic relations that form meaning, also referred to as coherence. Intercultural relations in a written discourse are arranged continuously and form a cohesion. The cohesiveness in meaning and orderliness of form in written discourse are the two most important factors in a discourse. Therefore, the competence of discourse analysis in this research refers to the aspects of cohesion and coherence.

Discourse analysis competence will lead a person, in this case, university students to produce more regular and systematic writing quality. For sentences to form a good and effective discourse, there are basic conditions that must be considered are cohesion and coherence. Therefore, discourse analysis competence especially the mastery and understanding of cohesion and coherence aspects are very important. Unfortunately, analysis of discourses, especially written discourse, is seldom accompanied by qualified discourse analysis competence. The written discourse analysis, especially in mastery of cohesion and coherence is still rather confusing, especially in written English discourse/text. This is in line with the results of preliminary observations in carried out by this study at Bina Darma University in Palembang. The authors found various obstacles faced by undergraduate students in the English study program at Bina Darma University in understanding and analyzing aspects of cohesion and coherence of each paragraph in a discourse. The problems observed in the classroom included lack of understanding of what has been read, lack of mastery of sentence structure, lack of interest and reading or writing skills, less enthusiasm in reading, understanding, and analyzing discourses, and little ability to develop ideas.

The problem of the low competence in discourse analysis, especially the mastery of cohesion and coherence is one of the causes of a low discourse analysis competence. This state of affairs in language learning is nor trivial and something to be avoided but rather something that needs to be researched on or investigated. This problem can be addressed by identifying in advance factors that can influence students' discourse analysis competence. Starting from the internal factors, it could be seen that one of the internal factors that could influence the competence of discourse analysis was reading interest. Following Khusniyah, Rasyid, and Lustyantie (2019) reading is very crucial since it broadens the learning and success in education. When analyzing discourse, students were required to read the discourse entirely. This, of course, required a great interest in reading from the students so that the activity of analyzing discourses could run effectively and smoothly.

Interest illustrates a student's tendency to approach rather than avoid involvement in certain content or actions, for example reading or writing, from time to time (Abbott et al., 2017). According to Anugra, Yusup, and Erwina (2013), reading interest, books and libraries are the three main elements in an education system that can create the quality of human resources. Nurhaidah and Musa (2016) state that individuals who have an interest in reading will be encouraged to pay attention to these activities. Interest is a feeling of love and eagerness in a thing or activity without the force of anyone. Someone who has an interest in certain activities tends to give great attention to these activities, including analyzing a discourse (Flora Siagian, 2015). Activities that are of interest to students are given constant attention, accompanied by pleasure and then a sense of satisfaction is gained. Likewise, if a student is interested in analyzing discourses, including discourse or reading texts in English, then he will tend to be more attentive, fond, happy, and familiar with the reading material he/she will try to analyze the discourse well. To analyze an English reading text, the reader must have an interest in reading. Interest in reading is an initial condition that must be met before reading and then analyzing. This reading interest is the basis of one's motivation for reading activities (Putri Maharani, Putu Arsana, \& Putu Dian Sawitri, 2015).

Interest in reading is an encouragement that can influence behaviour and actions which are then followed by feelings of pleasure and interest in reading activities. Evaluation of high and low interest in reading can be known through aspects of awareness of the benefits of reading, attention to reading books, feeling happy about reading books, and the frequency of reading books (Rahma, 2015). Students' low interest in reading leads reading habits. Reading interest influences students' reading comprehension (Rina Harsono, Fuady, \& Saddhono, 2012), so, it influences the competence of discourse analysis. In the process of reading, interest is very necessary. Because students will read fervently without being forced. Once the students have a high reading interest, it is expected that they will reach a high understanding, which enables them analyze the discourse well. By having an interest in reading, it is expected that the students can arouse the enthusiasm of reading, especially for students who are lazy to read as a negative result from outside themselves. The students can form good reading habits so that the ability to understand reading will be better and the ability to analyze a discourse can be improved.

Another factor which could also affect discourse analysis competence is achievement motivation. In reading, especially in analyzing a discourse, students needed a high motivation so that their concentration is maintained and able to analyze the discourse appropriately. Motivation is needed especially when students read and analyze long discourses. Motivation is a conscious effort to move and maintain a person's behaviour so that he is compelled to act on something to achieve certain results or goals (Hamdu \& Agustina, 2011). Motivation can also be interpreted as a physiological and psychological condition found in a person that drives him to do certain activities to achieve a certain goal or need. Salehi, Samimi, and Razmjoo (2018) note that if an educator (teacher/lecturer) wants to improve the language achievement of their students, the teacher/lecturer must first turn on student motivation and if the student motivation to learn languages, in this case, English is provoked, the students' perseverance in their learning, including analyzing discourses is improved. Bayanie (2013) explains that achievement is an indicator of motivation where individuals who are bound to the task will try harder and persevere so that they are more successful. 
Motivation is the most determining factor for a student (Potu, 2013). Motivation is also an internal process that activates, demands, and maintains behaviour over time (Sjukur, 2012). According to Karbalaei and Sanati (2015) motivation is related to language learning and consists of two types, namely instrumental motivation which is the desire to learn language because it will fulfil certain practical goals, such as getting a job, passing an exam, and others; and integrative motivation, which is the desire to learn languages to communicate with people from other cultures who speak that language.

Setyaningrum (2015) elaborates that the most important motivation for education is achievement motivation, where someone tends to struggle to achieve success or choose activities that are oriented towards success or failure goals. Santosa, Damayanti, and Dewi (2016) suggest that achievement motivation is the encouragement of internal psychology to do something to achieve a goal. In other words, motivation influences one's success, and so does the learning process.

Achievement motivation is an individual factor that comes from within the students. Good motivation in learning will show good results (Bagiarta, Karyasa, \& Suardana, 2015). As an encouragement from within oneself, achievement motivation plays a very dominant role for every student to achieve the highest and also as a driving force in students, encouraging efforts to achieve maximum learning outcomes (Zuhri, 2008). By having achievement motivation, a student will have a strong urge to read, understand, and then analyze a discourse. The student will have high self-esteem and a desire for achievement. All of those things will certainly affect the competence of students' discourse analysis. By having a high achievement motivation, of course, students also have a huge opportunity to achieve high achievement in discourse analysis courses which is shown by a high competence of students' discourse analysis.

Previous research has shown that reading interest and achievement motivation affect students' discourse analysis competence. Reading interest and achievement motivation play a major role in learning a second or foreign language since students' high or low interest and motivation largely determine the discourse analysis competence. This research is different from other previous research since the focus is on students' discourse analysis competence especially on cohesion and coherence aspects at tertiary level. Therefore, the authors in this research would like to find out whether reading interest and achievement motivation can serve as predictors of discourse analysis competence of the undergraduate students of the English Study Program at Bina Darma University. Particularly, the research aims to answer this study's guiding questions, which are: (1) Does reading interest influence students' discourse analysis competence? (2) Does achievement motivation influence students' discourse analysis competence?". In line with the problems of the research, the objectives are to investigate whether or not reading interest and achievement motivation influence students' discourse analysis competence. This research can hopefully give some information to teachers and parents to master the concept of reading interest and achievement motivation as factors that can affect the students' success or failure in analyzing discourses. For the students, this research is beneficial for them to understand their interest and motivation so that they can enhance their abilities in learning. They may also become effective problem solvers and more autonomous in their learning.

\section{Method of the Research}

This research uses a survey method with the path analysis technique. In this research, the respondents were not subject to any treatment but were given a test to obtain scores in discourse analysis competence $(\mathrm{Y})$, questionnaires for ascertaining reading interest $\left(\mathrm{X}_{1}\right)$ and achievement motivation $\left(\mathrm{X}_{2}\right)$. The population of this research comprised students of the English study program at Bina Darma University in Palembang. Meanwhile, the sample of this research was determined by random sampling technique on the students considered to have met the requirements necessary for conducting the research, so that the number of the sample in this research was 60 students.

Before administering the test and questionnaires, the test and questionnaires were piloted on other students who were not part of the sample of this research to check for their validity and reliability. The validity analysis used in this research was the corrected item-total correlation. Meanwhile, the reliability analysis used in this research was Cronbach's Alpha.

In this research, the instruments used were all reliable. The reliability of the reading interest questionnaire, achievement motivation, and discourse analysis test were $0.975,0.981$, and 0.991 respectively. Besides, the number of the valid items for reading interest questionnaire, achievement motivation, and discourse analysis test were 34, 33, and 31 items. The data gathered from the questionnaires and test were analyzed and processed by using SPSS 20. The inferential statistical analysis was used to do the calculation and to test the hypotheses, and also to generalize the research results. Before testing the hypotheses, the authors conducted test requirement analyses for normality and linearity. The normality test was intended to determine whether or not the distribution of the data was normal. The normality test used in this research was the One Sample Kolmogorov-Smirnov test. The data is declared normal if the probability value $>0.05$. The linearity test aimed to determine whether two variables significantly had a linear relationship or not, with a significance level of 0.05. It was known from the analyses that the data in this research was distributed normally with a significance value 0.189 , and linear for the reading interest and discourse analysis competence variables. Achievement motivation and discourse analysis competence showed a significance value 0.000 for each variable.

\section{Results and Interpretation}

Table-1. Illustration of Determinant Coefficient Value $\left(\mathrm{R}^{2}\right)$

\begin{tabular}{c|c|c|c|c|c|c}
\hline Model & R Square & F & Sig. & Standardized Coefficients (Beta) & t & Sig. \\
\hline $\mathrm{X}_{1}$ & \multirow{2}{*}{0.446} & \multirow{2}{*}{15.049} & 0.000 & 0.253 & 2.094 & 0.041 \\
\hline $\mathrm{X}_{2}$ & & & 0.284 & 2.546 & 0.014 \\
\hline
\end{tabular}

From Table 1, the determination coefficient value $\left(\mathrm{R}^{2}\right)$ is 0.446 , which means that $44.6 \%$ of the variability of the discourse analysis competence variable could be explained by reading interest and achievement motivation. The 
positive direct effect could be seen from the path coefficient shown by Beta (Standardized Coefficients) column. In Table-1 above, it was obtained consecutively: (1) py $1=0.253$; to $=2$,094, p-value $=0.041 / 2=0.020$ which was less than 0.05 or Ho was rejected, which means that reading interest $\left(\mathrm{X}_{1}\right)$ had a positive direct effect on discourse analysis competence $(\mathrm{Y}) .(2)$ py $2=0.284 ;$ to $=2.546, \mathrm{p}$-value $=0.014 / 2=0.007$ smaller than 0.05 or Ho was rejected, which means that achievement motivation $\left(\mathrm{X}_{2}\right)$ had a positive direct effect on discourse analysis competence $(\mathrm{Y})$.

The effect of reading interest on students' discourse analysis competence was proved by the t-test value of 2.094 with the significance of 0.041 which was smaller than 0.05 , which means that there was a partially significant influence of reading interest on the discourse analysis competence. The regression coefficient of 0.446 indicated a positive influence, meaning that the higher the interest in reading, the better the competence in analyzing discourses, and vice versa. This coefficient value also means that the competence of discourse analysis will increase by 0.446 in one improvement of reading interest. The magnitude of the coefficient of the direct effect of reading interest on discourse analysis competence was 0.253.

The effect of achievement motivation on students' discourse analysis competence could be proven by the tvalue of 2.546 and the significance of 0.014 which was smaller than 0.05 , which means that there was a partially significant influence of achievement motivation on the discourse analysis competence. The regression coefficient value of 0.446 indicated a positive influence which means that the higher the achievement motivation, the better the discourse analysis competence, and vice versa. This coefficient value also means that the competence of discourse analysis will increase by 0.446 in one improvement of achievement motivation. The magnitude of the coefficient of the direct effect of achievement motivation on discourse analysis competence was 0.284.

In this research, it was found that reading interest $\left(\mathrm{X}_{1}\right)$ had a positive direct effect on discourse analysis competence $(\mathrm{Y})$. Thus, an increase in reading interest will lead to an increase in the competence of discourse analysis $(\mathrm{Y})$. One of the internal factors that could influence the competence of discourse analysis was reading interest. When analyzing a discourse, students were required to read the discourse entirely. This certainly required a high interest in reading from within the student so that the activity of analyzing discourses could run effectively and smoothly. Interest is a feeling of love and eagerness in something or activity, without being compelled by anyone. Someone who has an interest in certain activities tends to give great attention to these activities, including analyzing a discourse (Flora Siagian, 2015). Activities which are interesting to students will be given constant attention, accompanied by pleasure and finally, a sense of satisfaction is gained. To analyze an English text, the reader must have an interest in reading. Reading interest is an initial condition that must be met before reading and then analyzing. This reading interest is the basis of one's motivation for reading activities (Putri Maharani et al., 2015). Reading interest influences students' reading comprehension (Rina Harsono et al., 2012), so, it influences the discourse analysis competence. In the process of reading, interest in reading is very necessary because students will read fervently without being forced. When the students have a high interest in reading, it is expected that they will reach a high understanding so that they can analyze the discourses well. By having an interest in reading, students are expected to be able to arouse their spirit of reading, especially for those who are lazy to read as a negative result from outside themselves. Furthermore, reading interest can form students' good reading habits, so that students' reading comprehension is getting better and the discourse analysis competence can be improved. Based on the theories and explanation above, it can be concluded that discourse analysis competence is influenced by reading interest. Therefore, the findings of this research empirically support the theories or findings of the experts that have been described previously.

Besides, it was also found that achievement motivation $\left(\mathrm{X}_{2}\right)$ had a positive direct effect on discourse analysis competence $(\mathrm{Y})$. Thus, an increase in achievement motivation will lead to an increase in students' discourse analysis competence. In reading, especially analyzing a discourse, students need a high motivation so that the concentration is maintained and able to analyze the discourse appropriately. Motivation is needed especially when students read and analyze a long discourse. Salehi et al. (2018) state that if an educator wants to improve the language achievement of their students, educators must first turn on the student motivation, and if students' motivation to learn languages, in this case, English has been provoked, then students can be expected to persevere in their learning, including analyzing discourses. People who are motivated will usually show an effort or reaction in achieving the desired goals. Thus motivation is the main support for humans in achieving all their dreams and life goals in various ways (Santosa et al., 2016). As an encouragement from within oneself, achievement motivation plays a very dominant role for every student to achieve the highest achievements and also as a driving force in students, encouraging efforts to achieve maximum learning outcomes (Zuhri, 2008).

By having achievement motivation, a student will have a strong urge to read, understand, and then analyze the discourses. The student will have high self-esteem and a desire for achievement. All of that thing will certainly affect the students' discourse analysis competence. Students who have high achievement motivation will try to obtain successful targets. Thus, students who have high achievement motivation have enormous opportunities to achieve high levels of success in every learning activity. By having high achievement motivation, students also have a huge opportunity to achieve high achievement in discourse analysis courses which is shown by the high competence of students' discourse analysis. This might be possible because students who have high achievement motivation will also have an inner urge to carry out learning activities as well as possible, have the resilience to the difficulties encountered in lectures and in analyzing discourse activities. Based on the theories and explanation above, it could be concluded that the discourse analysis competence is also influenced by achievement motivation. Therefore, the findings of this research empirically support the theories or findings of the experts that have been described previously.

\section{Conclusion and Recommendation}

In this research, it was concluded that reading interest $\left(\mathrm{X}_{1}\right)$ had a positive direct effect on the students' discourse analysis competence $(\mathrm{Y})$, with path coefficient value of 0.253 and a direct effect of 0.446 . In other words, reading interest significantly affects the level of discourse analysis competence of students. The higher the interest in reading, the better the competence of the students in analyzing discourses. Based on the findings of this research, it can be concluded that the research hypothesis which stated that "there is a positive direct effect of reading 
interest on the students' discourse analysis competence" is acceptable. Achievement motivation $\left(\mathrm{X}_{2}\right)$ had a positive direct effect on the students' discourse analysis competence $(\mathrm{Y})$, with a path coefficient value of 0.284 and the direct effect of 0.446. In other words, achievement motivation significantly affected the level of discourse analysis competence of the students. The higher the achievement motivation, the better the students' discourse analysis competence. Based on the findings of this study it could be concluded that the research hypothesis which stated "there was a positive direct effect of achievement motivation on the students' discourse analysis competence" was accepted.

Based on the results of the research, the writers argue that students should strive to always foster interest in reading, improve their reading habits both in the form of academic or non-academic books such as magazines, novels, journals, newspapers (printed media) or reading through the internet (electronic media). Reading activities should be done anywhere, for instance at home, at school, on the campus, in the library, even in other public places. Students who are fond of reading do not only obtain information and knowledge but also train their analytical competence so that in the end it will facilitate the process of analyzing discourses. Also, the learning process in educational institutions should be more relevant and supportive for the growth and improvement of achievement motivation. Students should have a level of self-awareness of the needs that drive their behaviour/actions and awareness of the learning goals that they want to achieve. Teachers and lecturers should act as motivators so that students are eager to read a lot of books that support the curriculum in their respective study materials to increase the achievement motivation. Analyzing an English discourse requires high motivation because English is a foreign language. High motivated students tend to have deeper analysis. Finally, further research with a broader scope should be able to identify a variety of other variables that can affect the students' discourse analysis competence.

\section{References}

Abbott, R., Mickail, T., Richards, T., Renninger, K., Hidi, S. E., Beers, S., \& Berninger, V. (2017). Understanding interest and self-efficacy in the reading and writing of students with persisting specific learning disabilities during middle childhood and early adolescence. International Journal of Educational Methodology, 3(1), 41-64.Available at: https://doi.org/10.12973/ijem.3.1.41.

Anugra, H., Yusup, P. M., \& Erwina, W. (2013). Dominant factors that influence student reading interest exploratory survey about student reading interest in UPT ITB library. Journal of Information and Library Studies, 1(2), 137-146.

Bagiarta, I. N., Karyasa, I. W., \& Suardana, I. N. (2015). Comparison of TIPE GI (group investigation) science literacy and guided inquiry learning models in terms of the achievement motivation of junior high school students. Journal of Science Education and Learning, $5(1), 1-11$.

Bayanie, M. (2013). Relationship between achievement motivation and self concept with creative attitude. Journal of Early Childhood Education, 7(1), 1-15.

Flora Siagian, R. E. (2015). The influence of students' interest and study habits on mathematics learning achievement. Jurnal Formatif, 2(2), $122-131$.

Hamdu, G., \& Agustina, L. (2011). The effect of student motivation on science learning achievement in elementary school. Educational Research Journal, $12(1)$, 90-96.

Karbalaei, A., \& Sanati, F. (2015). The study of the relationship between emotional intelligence, reading motivation, and anxiety with reading comprehension among Iranian EFL learners. International Journal of English Language and Literature Studies, 4(4), 171-183.Available at: https://doi.org/10.18488/journal.23/2015.4.4/23.4.171.183.

Khusniyah, N. L., Rasyid, Y., \& Lustyantie, N. (2019). Improving English reading comprehension: The role of visual mind mapping SQ4R strategy. Paper presented at the Paper Presented at the 2nd International Conference of Science and Technology for the Internet of Things, September 3rd 2019, Yogyakarta, Indonesia.

Nurhaidah, \& Musa, M. I. (2016). The impact of low interest in reading among PGSD Lampeuneurut students in Banda Aceh and how to improve it. Jurnal Pesona Dasar, 3(4), 1-11.

Potu, A. (2013). Leadership, motivation, and work environment influence on employee performance in kanwil ditjen sultenggo and Maluku Utara in Manado. EMBA Journal, 1(4), 1208-1218.

Putri Maharani, A. A., Putu Arsana, A. A., \& Putu Dian Sawitri, N. L. (2015). Improve students' reading comprehension through affinity strategies and authentic reading material. Bakti Saraswati Journal, 4(1), 8-23.

Rahma, N. M. (2015). Strategies for increasing children's reading interest study on children reading Room public library and regional archives of malang city. Jurnal Administrasi Publik, 3(5), 763-769.

Rina Harsono, A. S., Fuady, A., \& Saddhono, K. (2012). The influence of KWL strategy and interest in reading on the intensive reading ability of state junior high school students in temanggung. Basastra Journal of Language, Indonesian Literature and Teaching Research, $1(1), 53-64$.

Salehi, N., Samimi, F., \& Razmjoo, S. A. (2018). The impact of a pedagogical, classroom-based motivational intervention on EFL learnerse reading achievement. Studies, 6(1), 126-133.Available at: https://doi.org/10.1093/applin/amu021.

Santosa, A. B., Damayanti, A., \& Dewi, S. U. (2016). The perception of cooperative learning models and achievement motivation for learning outcomes of English courses. Dewantara Journal, 2(2), 148-164.

Setyaningrum, A. (2015). Effect of parental social support on achievement motivation of fifth grade elementary school students. Journal of Primary School Teacher Education, 17(4), 1-10.

Sjukur, S. B. (2012). The influence of blended learning on learning motivation and student learning outcomes at the SMK level. Journal of Vocational Education, 2(3), 368-378.

Zuhri, M. H. (2008). Cooperative learning, jigsaw techniques, achievement motivation, and geography learning outcomes for high school students. Journal of Educational Sciences, 15(1), 26-34. 